Paideusis

\title{
Taking on the Traditions in Philosophy of Education: A Symposium
}

\author{
David P. Burns, Ann Chinnery, Claudia W. Ruitenberg and David I. \\ Waddington
}

Volume 18, Number 2, 2009

URI: https://id.erudit.org/iderudit/1072328ar

DOI: https://doi.org/10.7202/1072328ar

See table of contents

Publisher(s)

Canadian Philosophy of Education Society

ISSN

0838-4517 (print)

1916-0348 (digital)

Explore this journal

Cite this article

Burns, D., Chinnery, A., Ruitenberg, C. \& Waddington, D. (2009). Taking on the Traditions in Philosophy of Education: A Symposium. Paideusis, 18(2), 3-18.

https://doi.org/10.7202/1072328ar

\section{Article abstract}

In this symposium, we highlight the importance of critical engagement with philosophical traditions in philosophy of education. On one hand, it is important to critique the exclusionary nature of canons of knowledge that have shaped both philosophy and education; on the other, we believe it is important to acknowledge that our thinking, as well as the thinking of philosophers of education before us, is undeniably and indelibly marked by these traditions. Framed by Jacques Derrida's reflections on the "figure of the philosopher" and Michael Naas's conception of "taking on the tradition," David Burns invites us to revisit the Stoic conception of character as a counterpoint to current discourses of character education in Canadian schools; David Waddington examines how Thomas Jefferson's writings influenced John Dewey's conception of democracy and democratic education; and Ann Chinnery proposes acknowledgement of intellectual indebtedness as an essential scholarly disposition, looking specifically at the "difficult inheritance" of Emmanuel Levinas's debt to Martin Heidegger.
(C) David P. Burns, Ann Chinnery, Claudia W. Ruitenberg, David I. Waddington, 2009

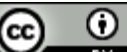

This document is protected by copyright law. Use of the services of Érudit (including reproduction) is subject to its terms and conditions, which can be viewed online.

https://apropos.erudit.org/en/users/policy-on-use/ 


\section{Taking on the Traditions in Philosophy of Education: A Symposium}

\author{
DAVID P. BURNS \\ University of Alberta \\ Canada
}

DAVID I. WADDINGTON ${ }^{1}$

Concordia University

Canada

\author{
ANN CHINNERY \\ Simon Fraser University \\ Canada
}

\author{
CLAUDIA W. RUITENBERG \\ University of British Columbia \\ Canada
}

In this symposium, we highlight the importance of critical engagement with philosophical traditions in philosophy of education. On one hand, it is important to critique the exclusionary nature of canons of knowledge that have shaped both philosophy and education; on the other, we believe it is important to acknowledge that our thinking, as well as the thinking of philosophers of education before us, is undeniably and indelibly marked by these traditions. Framed by Jacques Derrida's reflections on the "figure of the philosopher" and Michael Naas's conception of "taking on the tradition," David Burns invites us to revisit the Stoic conception of character as a counterpoint to current discourses of character education in Canadian schools; David Waddington examines how Thomas Jefferson's writings influenced John Dewey's conception of democracy and democratic education; and Ann Chinnery proposes acknowledgement of intellectual indebtedness as an essential scholarly disposition, looking specifically at the "difficult inheritance" of Emmanuel Levinas's debt to Martin Heidegger.

\section{Introduction (Claudia Ruitenberg)}

In Amy Kofman and Kirby Dick's film Derrida, Dick asks Derrida: "If you had a choice, what philosopher would you have liked to have been your mother?"2 Derrida, who is visibly both surprised and amused by this question, takes some time to think this over, then shakes his head and answers,

I'll try to tell you why it's impossible for me to have any philosopher as a mother. My mother couldn't be a philosopher. Or, a philosopher couldn't be my mother. That is very important. It says a lot. Because the figure of the philosopher is, for me, always a masculine figure. This is one of the reasons I undertook the deconstruction of philosophy. ${ }^{3}$

Derrida here indicates his acknowledgement of the gendered character of Western philosophical traditions, and in fact identifies this gendered character as one of the reasons for his life's work, the deconstruction of philosophy. A casual reader of Derrida's work, however, might observe that his

(C) Copyright 2009. The authors, David Burns, Ann Chinnery, Claudia Ruitenberg, and David Waddington, assign to Paideusis the right of first publication and educational and non-profit institutions a non-exclusive license to use this document for personal use and in courses of instruction provided that the article is used in full and this copyright statement is reproduced. Any other usage is probibited without the express permission of the authors. 
engagement with Western philosophical traditions-including key authors such as Plato, Aristotle, Kant, Heidegger and Husserl—reinscribes the masculine and Eurocentric figure of philosophy.

In this symposium, we want to highlight the centrality of this critical relation with philosophical traditions for philosophy of education. On one hand, it is important to critique the exclusionary nature of canons of knowledge that have shaped both philosophy and education; on the other, we believe it is important to acknowledge that our thinking, as well as the thinking of philosophers of education before us, is undeniably and indelibly marked by these traditions. We are inheritors of philosophical traditions, warts and all, and we can "take on" these traditions only by acknowledging them and, as I have argued elsewhere, coming to critical terms with our inheritance. ${ }^{4}$

I borrow the phrase "taking on the tradition" from Michael Naas, who studied with Derrida and acknowledges his enduring debt to Derrida's work. ${ }^{5}$ Writes Naas, "it is always the other who signs, who authorizes us or gives us the power to speak, who leaves a tradition or history to work, with or against, who situates us with a name, a place, and a time." 6 Taking on the tradition means receiving it, but not with an uncritical reverence. As Derrida demonstrates in his answer to the question of what philosopher he would have liked to have been his mother, he has taken on the Western philosophical tradition precisely to contest its implied impossibility of the feminine figure of the philosopher.

Perhaps nowhere is the challenge of taking on the tradition outlined more sharply than in the case of Emmanuel Levinas, the Lithuanian-French Jewish philosopher who faced having to acknowledge his intellectual indebtedness to the work of Martin Heidegger, while Heidegger's Nazi sympathies deeply violated Levinas's Jewish beliefs, identity, and family history. In this symposium Ann Chinnery draws on the work of Roger Simon, Sharon Rosenberg and Claudia Eppert to analyze this "difficult inheritance" and to argue that, while most philosophers of education fortunately face inheritances less difficult than Levinas's, acknowledgement of intellectual indebtedness should be a scholarly disposition for all of us. ${ }^{7}$ Thinking not only of anti-Semitic traces in philosophical traditions but also of colonial, patriarchal and other exclusionary traces, she considers what it might mean to be faced with the inescapable task of taking up and carrying a debt that one cannot reasonably bear.

In recent years some philosophers of education, perhaps under the influence of such "difficult inheritance," have turned away from the external or received knowledge of philosophical traditions to focus on the internal or subjective knowledge of personal experience. ${ }^{8}$ The suggested dichotomy between subjective and received knowledge, however, is false, and we argue that it is only through a critical examination of our intellectual traditions that we can come to understand our own thinking today. David Burns, for example, takes an approach to moral education that is influential in Canada today, and examines both its dominant, Aristotelian history and a possible Stoic reconception. The concept of "character" in character education today is typically understood as involving a set of virtues addressing various dispositions, but for the Stoics virtue is reason. While contemporary moral education stands to benefit from a reconsideration of Stoic philosophy, it must also be willing to critique this inheritance.

David Waddington revisits the work of one of the most influential modern philosophers of education: John Dewey. Many philosophers of education have read Dewey's better-known works such as Democracy and Education, and the influence of Darwin's work on Dewey is well documented. Fewer know, however, that Dewey's ideas about democracy and education were also influenced by Thomas Jefferson, an author with whose work Dewey himself was unfamiliar prior to being commissioned to edit a book on Jefferson's thought. Reading Jefferson's writings inspired Dewey's book Freedom and Culture, as well as his essay "Creative Democracy," but this should not obscure the more objectionable aspects of Jefferson's work.

Burns and Waddington occupy themselves with philosophers and philosophical work that appear almost unfashionably classical these days. By doing so, they do not uncritically embrace everything the Stoics or Dewey and Jefferson had to say, but they demonstrate the value of acknowledging and tracing philosophical traditions in order to come to deeper understandings of current practices, as well as of the authors we read. First, then, let us turn to the Stoics. 


\section{Stoicism and Seneca (David Burns)}

Seneca tells of a fantastically rich man who, through financial trouble, became merely a rich man. ${ }^{9} \mathrm{He}$ had convinced himself that he needed hundreds of millions of sesterces (Roman currency) to survive, so when his fortune dwindled to ten million he killed himself. In telling this story Seneca emphasizes that some people dream of having ten million sesterces, while others find this to be an unbearably small amount. Given this difference, "what folly...to think that it is the amount of money and not the state of mind that matters!"”10 This man did not kill himself merely because he had lost vast sums of money, but because he had lost vast sums of money and he believed he could not go on (flourish) without those sums. Clearly, Seneca argues, we feel and act in certain ways both because of things that happen in the world around us and because of the beliefs we have about those things. The Stoics argue, in light of this view of ethical life, that one ought to form such beliefs in certain ways and that only in doing so can one flourish.

This point brings us to an important foundation of Stoic ethical philosophy. At its root, Stoicism holds a common tradition with other classical virtue theories in being eudaimonist, which is to say, it holds that "we all seek happiness" or flourishing. ${ }^{11}$ It differs, though, in what exactly that happiness is. More precisely, it draws different lines as to what is required to be happy. For Seneca, a happy life is one that is "in harmony with its own [human] nature."12 This nature, to Seneca, is reason. He concludes: "this reason, when fully developed, is called virtue, and is also, objectively, the moral ideal." 13 Ethical action, in this case, is action which arises out of perfected reason and which is not polluted by other factors. According to Seneca, action against reason is the very definition of vice.

This vice is arrived at when reasoning becomes dependent upon something outside of itself. Since one may influence but not direct those things that happen around one, to rely on them and allow one's reasoning to be enslaved by them is the very "depth of servitude."14 True and lasting happiness can only be achieved through placing the good outside of the reach of those things in the world that one cannot control: pleasure, pain, wealth, poverty, health, sickness etc. To pursue such things as if they were goods is to dispose oneself to irrational and therefore vicious action. One ought, according to the Stoics, to view such things indifferently with respect to the good. It is for this reason that the Stoics refer to these things as indifferents. This brings us back to the wealthy Roman. He believed wealth was a good, felt that he could not go on without it, and subsequently acted to end his life. This problem seems to extend to other-regarding vices as well. If wealth is perceived as a good, actions that accumulate it are good in much the same way that altruistic actions are a good to the person who values selflessness. Viewing external things as goods also gives one a strong reason not to share such things, or perhaps even to pursue them at the cost of other persons. ${ }^{15}$

In discussing the potential of this line of argument it is important to reinforce that it is not indifferents themselves that are being rejected, but rather irrational dependence upon them. A Stoic faced with poor health, to use Seneca's words, "will endure it, but he will wish for good health."16 To return to the Roman story, the man was not wrong to choose or prefer wealth but rather wrong to become so blindly and irrationally attached to it. While "the wise man finds in riches, rather than in poverty, this ampler material for displaying his powers," 17 he does not become dependent upon such riches.

The status of those things the Stoics call indifferents is a point of significant divergence between the Stoics and their Aristotelian interlocutors. Both positions acknowledge that certain external things, like wealth, may be relevant to happiness but they strongly disagree on whether those things are required for happiness. As Aristotle clearly states in his Nicomachean Ethics, "it seems clear that happiness needs the addition of external goods...for it is difficult if not impossible to do fine deeds without any resources." "While this statement might appear to be quite similar to the one quoted from Seneca about the "ampler material" to display virtue when one is wealthy, the differences are quite significant. In accepting a certain role for external goods Aristotle allows fortune into his discussion of virtue, a position with which the Stoics strongly disagree. Aristotle is willing to accept, for example, that being 
ugly is relevant to happiness. ${ }^{19}$ One may, he argues, be prevented from expressions of virtue by a lack of external resources. For Seneca, perfected reason depends on nothing outside of itself.

\section{Stoicism and Moral Education}

To apply this philosophy I now move to a November 2008 article of The Globe and Mail that reports rising concern among students and law enforcement officers about the theft of personal music players. ${ }^{20}$ Several students, when asked about the theft of such devices, responded by emphasizing the emotional significance of having one stolen. Statements like "I'd rather be stabbed than give up my iPod," or "There goes my life," draw attention to the way in which these students view these products.

A Stoic moral educational analysis of this situation could begin with Mark Holowchak's teacheras-physician concept. ${ }^{21}$ Drawing on a number of Stoic philosophers, Seneca among them, he explains that the Stoic teacher is something like a physician for the soul. Since the Stoics view the root of happiness as a particular kind of understanding, embodied in our disposition to the world around us, they view Stoic education as a treatment for poorly formed understandings and dispositions. Such problems cause the patient to literally suffer from ignorance (as the Roman man did). Until this ignorance is addressed, actions and feelings will be guided by irrational attachments and beliefs and the patient will find their flourishing compromised. The task, then, falls to the teacher to foster "curative" learning. ${ }^{22}$

Following Holowchak, such a teacher would first attempt to ascertain what sort of illness of character is at play. If a student is willing to harm and steal to obtain an indifferent, he or she clearly holds a view of such things that places them in an ethically powerful role. The pedagogical element of the solution, then, must provide a learning opportunity that includes reexamination of the role of external goods. The student must be given the tools to come to more defensible beliefs about the significance of conveniences like personal music players.

The view that these objects are goods provides one with a compelling reason to steal them. So long as that reason persists the student will be forever tempted by a character built on unsatisfied material desire. From a Stoic pedagogical perspective, this situation becomes an important opportunity to draw such a student into a conversation about the relationship between one's character and one's view of things like music players. Interestingly, this argument also begs the question of whether there might also be a problem evident in the character of the victims. Clearly, the fact of having one's property stolen does not itself provide reason to question one's character. The quoted responses to this crime, however, do provide an interesting entry point for a Stoic moral educator. Recall the following comments:

A: "I'd rather be stabbed than give up my iPod"

B: "There goes my life"

In both cases the students are making statements that convey the significance of their music player to their lives. Student A is clearly indicating that her iPod is of such significance that she views it as comparable to her physical well being. Student B is referring to his life in such a way that the term seems to imply that his iPod is closely linked with his view of living. The clear personal distress caused by losing (or thinking about losing) their iPods could lead a Stoic moral educator to conclude that each student suffers from an irrational attachment to this particular indifferent. Both appear to view their possession of such a device in way that ties this possession closely to their personal flourishing. Its absence is seen as the absence of something pivotally good. Much like the Roman man, these two students have formed a belief that disposes them to take irrational action (such as risking serious injury over a music player).

Indeed, one comes to see that the vice of the thief is the same as the vice of the distraught victims, differing only in extent. Give all three students an opportunity to engage in critical analysis of the implications of these beliefs, and it becomes possible to address both the reason to steal and the reason to feel bad at having been stolen from. In short, moral education should include opportunities 
for Stoic self-analysis. Why do I feel the way I do when I buy something or lose something? Is this who I want to be? How do my beliefs about things motivate me to act? Are these defensible beliefs?

\section{Problems of Inheritance}

These questions have the potential to spur fruitful and novel discussion in contemporary classrooms. There is value, then, in seeking to draw this philosophical insight into conversation both about moral education and in moral education. This philosophical inheritance is, however, a very difficult one. Anyone proposing contemporary use of Stoicism in education (or any other field) must contend with a number of serious issues that threaten to undermine such efforts. While there are a significant number of possible difficulties, I will discuss one central example here: the problem of partial adoption or revision.

The first thing a modern reader of Stoicism often notes is the radical approach the Stoics take to ethical life. While Aristotle seeks merely to moderate the passions, for example, the Stoics seek to extirpate them altogether. Read from a skeptical perspective, Stoic arguments like these are radically implausible suggestions that no actual person could, or should, live up to..$^{23}$ Read from a sympathetic perspective, such arguments are radicalized articulations of helpful therapeutic ideas. ${ }^{24}$ The question for a modern-day educator, then, is to what extent one might moderate Stoicism in order to draw out its most helpful elements. This inquiry leads one to the difficult process of revising Stoic thought without losing its philosophical core. Can one accept certain dependencies, such as those dealing with other people, without becoming too vulnerable? Can one tentatively accept the goodness of certain worldly things? Must one deploy one's rational capacities to minimize all of one's passions? These questions are difficult ones, and the value of the Stoic inheritance can only be found in delicately answering them.

As an example, when Seneca was exiled from Rome he found himself without the comfort of his privileged former life. On the occasion he wrote a letter of consolation to his mother Helvia, ${ }^{25}$ bidding her not to feel badly for him. In this letter, Seneca engages in an extended Stoic argument about the proper way to view such an exile. He glorifies the life of quiet contemplation that now lies before him, and exalts his surroundings because they lack the distractions of his former circumstances. Indeed, the picture Seneca paints of his new life is one of gratitude. Without the confusing and obfuscating influences of Roman life and culture he is now better situated to pursue the demands of virtue, he argues. What is a modern reader to make of such a position? Is it truly better to separate oneself from society or is this merely an attempt to use a philosophical method to assuage a particular person's grief? The latter seems most consistent with Stoic thought, but this question is far from easily settled and cannot be discussed satisfactorily here. Furthermore, the heavy emphasis the Stoics place on their teleological arguments, which are largely rejected today, makes such inquiry all the more difficult. It is not immediately clear, for instance, how one might draw profitably from Stoic thought without falling into the position of justifying a seemingly callous form of individualistic rationalism. The figure of Seneca exalting in total exclusion appears to lead one down this path. What is clear from this discussion is that the wisdom the Stoics have passed on through the millennia is not easily inherited. Indeed, how one makes good philosophical or pedagogical use of Stoic thought depends very much on how one intends to inherit it. Do we pick and choose elements that stimulate useful discussion or inquiry? Do we tie the Stoic system into a single package, to be taken or left in its entirety? What might we safely discard or revise? Like much of our intellectual inheritance, we do not always know quite what to do with it. 


\section{Looking Back, Looking Forward: Dewey's Admiration of Jefferson (David Waddington)}

From the space of reflection opened by Stoicism, we turn to John Dewey's reflection upon and reconstruction of the work of Thomas Jefferson. In the late 1930s, John Dewey developed a sudden admiration for Jefferson-he edited a volume of Jefferson's writings (The Living Thoughts of Thomas Jefferson), and he remarked to his friend Max Otto, that he had "used [his] new knowledge of T.J." in writing Freedom and Culture (1940). ${ }^{26}$ This connection between two great American thinkers has never been subject to any significant historical analysis, and, as a result, some questions remain unanswered: Why was Dewey suddenly passionate about Jefferson, and did reading Jefferson inspire any new directions in Dewey's thought? As I will explain, Jefferson's ideas are, in many ways, congruent with those of Dewey, and he provided Dewey with the authority to make certain claims about American culture and democracy that are important to the argument in Freedom and Culture. In addition, Jefferson can be viewed, in certain respects, as the embodiment of Dewey's ideal citizen. However, although his reconstruction of Jefferson allowed Dewey to strengthen and renew his analysis of American democracy, it also contains a significant elision that is worthy of note, particularly from the perspective of "taking on traditions."

\section{Dewey and Jefferson in Freedom and Culture}

In Freedom and Culture, Dewey confronted the problem of totalitarianism. He felt that in the face of totalitarian threats from Germany and the Soviet Union, a case needed to be made for democracy as a strong and vigorous alternative. A surface commitment to democratic institutions was not enough, in and of itself, to stand against these threats. What was needed, instead, was for culture (by which Dewey meant the general way in which human beings associate with one another ${ }^{27}$ ) itself to become free. ${ }^{28} \mathrm{~A}$ culture of freedom would value freedom, in both its positive and negative senses - in its economic and educational institutions, in its media, and simply in terms of daily interactions. A society that was committed to freedom at this deep level would, Dewey felt, be in an excellent position to resist totalitarianism.

This point about democracy and culture, which is the cornerstone of the book, was grounded in Jefferson's thought. At several points in the narrative, Dewey referred to Jefferson's fear that social change would erode the democratic spirit. Jefferson commented:

The mobs of great cities add just so much to the support of pure government, as sores do to the strength of the human body. It is the manners and spirit of a people which preserve a republic in vigor. A degeneracy in these is a canker which soon eats to the heart of its laws and constitution. ${ }^{29}$

Although Jefferson did not use the contemporary language of culture, his remark about "the manners and spirit of a people" indicates that he was making essentially the same point that Dewey later made. This similarity cannot be accidental: in another letter to Otto, Dewey commented, "[Jefferson] certainly was intensely aware of the conjunctions of circumstances that made the new gov't possible-and fearful they wouldn't last." 30 He further noted that he had deliberately chosen to emphasize this point in Freedom and Culture and that this point had come to him while reading Jefferson. ${ }^{31}$

Having derived his core thesis about the connection between freedom and culture from Jefferson, Dewey spent most of the rest of the book attacking what he viewed as simplistic understandings of how the shape of culture is determined. Ultimately, he concluded that many different factors played into the formation of culture and that the question eluded simple resolution. Jefferson recedes into the background for some of this analysis, but Dewey returned to him forcefully towards the end of the book, where he offered some prescriptions for moving forward. Dewey began these 
prescriptions with an attack on those who want to keep particular democratic institutions frozen in time. He remarked, “The most flagrantly obvious violation of Jefferson's democratic point of view is found in the idolatry of the Constitution as it has been sedulously cultivated... ." ${ }_{2}$ Jefferson believed (as did Dewey) that new generations would need to design new institutions which would accord with "new discoveries, new truths, change of manners and opinions." 33 Dewey also focused on Jefferson's emphasis on the local community. Grappling with human problems, Dewey felt, required "emphatic attention to the need for face-to-face association"- if the desire for community were not attended to in this way, it would be catered to by "rabblerousers" through mass movements. ${ }^{34}$

\section{Thomas Jefferson: The Ideal Deweyan Citizen?}

Freedom and Culture clearly shows that Dewey admired Jefferson. The motivating force behind this admiration, however, becomes clearer in the introduction that Dewey wrote for The Living Thoughts. Jefferson, in many ways, embodied the ideal of the engaged, science-savvy citizen to which Dewey was dedicated throughout his work.

Dewey's enduring faith in science is well known, and it is manifest even in his earliest work. In an 1895 essay, Dewey criticized the French thinker Ernest Renan for the loss of his youthful 1848 faith in the power of science to change social and political conditions. ${ }^{35}$ Dewey commented on Renan's original view:

I may sum up by saying that Renan's faith in '48 was that science was to become universalized-universalized in its range by coming to include humanity as its subject matter; universalized in application by being made, as to its salient outcome, the common possession of all men. ${ }^{36}$

Dewey remained committed to the essence of this view throughout his career as a thinker. He felt that the problems of humanity needed to be considered from a scientific standpoint, and, in keeping with this, he maintained that citizens have to be capable of thinking scientifically.

Jefferson, like Dewey, was strongly committed to science. In his introduction to the Jefferson book, Dewey quoted from one of Jefferson's letters, in which he remarked, "Nature intended me for the tranquil pursuits of science by rendering them my supreme delight." ${ }^{\prime 37}$ This was not an exaggeration on Jefferson's part-he had a passionate and multifaceted interest in the subject. ${ }^{38} \mathrm{He}$ was an excellent naturalist, procuring specimens, analyzing them, and engaging in correspondence with scientists in Europe. ${ }^{39} \mathrm{He}$ invented several new tools (e.g., a portable writing desk, an improved plough), and he was committed to improving agriculture-during his time in Europe, he was constantly sending promising plants back to America. 40

In addition to being a practicing scientist, Jefferson was committed to a scientific approach to politics. Dewey pointed out that Jefferson thought of the American government "as an experiment." In accordance with this, Jefferson felt that citizens needed to be educated appropriately so as to be intelligent participants in the democratic experiment. He was a pioneer in the development of public education; he remarked that good government depended not on "the state of science, no matter how exalted it may be in a select band of enlightened men, but on the condition of the general mind." order to improve the "general mind," Jefferson developed a limited scheme of public education, and he was also instrumental in the founding of the University of Virginia. ${ }^{43}$

It is not difficult to see why Dewey thought it was worthwhile to look back to Jefferson; in many ways, Jefferson embodied the Deweyan ideal of democratic citizenship-he was an open-minded, experimental thinker who understood both the significance of science and technology as well as the importance of local community. However, Jefferson also had some significant failings, and Dewey, interestingly, chose to overlook these. 
The most significant of these was Jefferson's support of slavery. One can try to exculpate Jefferson on this issue by citing his comment in the Declaration of Independence that "all men are created equal," or by pointing to his comments in the Notes on Virginia in which he condemned slavery on the grounds that it had a cancerous effect on the "manners" of the nation. 44 However, this exculpatory effort is a doomed project. At the time of the writing of the Declaration of Independence, Jefferson owned about 200 slaves, and was one of the largest slaveholders in his county. ${ }^{45} \mathrm{It}$ is also likely that he had a longstanding sexual "relationship" with one of his slaves, Sally Hemings, and, in addition to all of this, he adhered to some particularly virulent racialist theories. ${ }^{46}$ Thus, even judged against the rather low standard of contemporaneous slave owners such as Washington (who, unlike Jefferson, freed his slaves after his death), he does not fare particularly well.

\section{The Question of Inheritance in Dewey}

Why did Dewey not mention Jefferson's failings? Certainly, he had to be aware of at least some of them; anyone who reads the Notes on Virginia will not fail to notice Jefferson's racialism. One possibility is that he omitted them because he was trying to recover and reconstruct Jefferson for the present. We know that Dewey was committed to the task of reconstruction in general, and, in particular, to the task of rebuilding historical thinkers in order to make their thought into useful tools to address current difficulties. ${ }^{47}$ Both Freedom and Culture and The Living Thoughts of Thomas Jefferson represent a conscious attempt to reconstruct Jefferson. ${ }^{48}$ There is an important passage in Freedom and Culture in which Dewey suggested that Jefferson's thought could be read as compatible with "equalization of economic conditions." This interpretation is unorthodox, and Dewey acknowledged that some might think he was attributing to Jefferson "ideas not present in his mind." 49 In fact, this charge is probably true, but this should not be surprising-Dewey was trying to put forward a version of Jefferson that would prove helpful in addressing the problems that were facing America at the time.

Yet even if one concedes that the task of reconstructing Jefferson is worthwhile, the question remains as to whether Dewey engaged in the right kind of reconstruction. Unlike Levinas in the case of Heidegger, Dewey does not acknowledge the difficulties of the Jeffersonian tradition upon which he is building in Freedom and Culture. Reconstruction, for Dewey, seems to imply more of an emphasis on looking forward than on looking back.

Of course, this begs the question of how we should address our inheritance from Dewey. Although the Deweyan inheritance is quite different from the Heideggerian one, a struggle to reconstruct is just as necessary in Dewey's case. There are substantial difficulties in Dewey's thought: Dewey had a concept of community that was strong to the point of being invasive, his faith in science and technology was overweening, and, as we have seen, he had a tendency to look toward the future rather than carefully analyze the past. Ironically enough, it was, in part, these problematic tendencies that so endeared Jefferson to Dewey and which may have enabled him to overlook Jefferson's faults. However, it is possible to recover traditions from Jefferson (and from Dewey and other thinkers) and simultaneously acknowledge that there is a significant amount of baggage that accompanies these traditions. Perhaps, as philosophers and historians of education, this "eyes-wide-open" reconstruction is one of our pressing tasks. ${ }^{50}$

As we shall see in the next section, Levinas pointed the way toward doing this. In a short 1935 essay, "Reflections on the Philosophy of Hitlerism," Levinas used part of Heidegger's own analysis from Being and Time to explain the appeal and danger of Nazism. ${ }^{51}$ Although he did not acknowledge this explicitly in the essay, Levinas probably knew that certain aspects of Being and Time led toward the position that Heidegger took up in the 1930s. Yet instead of regarding Heidegger's work as irredeemably tainted, Levinas realized that certain aspects of Heidegger's analysis could be repurposed to buttress an anti-fascist conclusion. Four years later, Dewey, a lifelong exponent of freedom, reinterpreted the ideas of Jefferson, a slave owner, to fight oppression. In retrospect, we might admit he 
did not appropriate Jefferson as thoughtfully as he might have, but the task facing him at the time was urgent.

Looking at Dewey's analysis of Jefferson in the light of today, we can see several worthwhile possibilities for reconstruction. With some critical attention and transformation, Jeffersonian and Deweyan ideals of scientific citizenship are relevant in the context of a society saturated by science and technology. But, perhaps most importantly, the issue of the promotion of democratic culture still looms large. When he was writing Freedom and Culture in 1939, Dewey worried that our commitment to democratic institutions was not deep enough; we were committed to the formal institutions of democracy, but we were not democratic in the deep, cultural sense. This criticism is still valid, especially in the North American context. The discourse on class has largely disappeared from the intellectual landscape in both the U.S. and Canada, and not because class differences are getting any smaller. Corporations are increasingly positioned as powerful political actors. In short, in terms of promoting a democratic culture, there is a great deal of reconstructive work ahead. Grappling with our intellectual traditions-whether they are in Stoicism, Deweyan thought or Continental philosophy-may prove vital in this task.

\section{The Unbearable Burden of Intellectual Indebtedness (Ann Chinnery)}

In this section, I want to step back a bit in order to look at intellectual indebtedness more generally, and to propose acceptance of intellectual indebtedness as an essential scholarly disposition. By intellectual indebtedness I mean a particular species of scholarly humility which begins in a recognition that anything we can claim to know comes from traditions that precede our own knowledge and which, more importantly, calls us to approach those traditions not simply as relics from the past, but as legacies that make ethical demands on us here and now. Intellectual indebtedness is thus marked by a disposition to see scholarly activity as equal parts intellectual pursuit and ethical obligation.

My motivation for this paper came from an observation that there is an increasing tendency to dismiss or disavow-often in the name of diversity and inclusion-scholarly traditions that carry histories of exclusion. As Ruitenberg acknowledged in her opening remarks, many of the philosophical and scientific traditions from which our own work derives are tainted by histories of exclusion of one kind or another. Western philosophy, for example, long excluded work by women and people from cultural and racial minorities, as well as non-textual forms of representation, non-Western epistemologies, and so on; and these exclusions have arguably been to the detriment of the discipline. But she also noted that to acknowledge our debt to philosophical traditions is not to take up those traditions slavishly or uncritically. Rather, in the spirit of Jacques Derrida and others, we are called to take on the traditions, to receive them and to work either with or against them.

In making a case for acceptance of intellectual indebtedness as a disposition particularly suited to taking on the traditions, I draw primarily on Roger Simon's work on remembrance and historical consciousness, ${ }^{52}$ which in turn draws on Emmanuel Levinas's ethics of unconditional responsibility, ${ }^{53}$ Derrida's work on hospitality and the "gift of the ghost," ${ }^{4}$ and psychoanalytic thought. I then look at Levinas's indebtedness to his teacher and mentor Martin Heidegger as an especially difficult inheritance.

\section{Indebtedness as a Difficult Inheritance}

"One consequence of the recent 'turn to ethics' in social and political thought," Simon writes, "has been a return to the question of what it could mean to live historically, to live within an upright attentiveness to traces of those who have inhabited times and places other than one's own." 55 To live historically means that we must attend carefully to how we read, view and listen to the experiences of 
others. It means that we must acknowledge our debt to those who have come before, and live as if the lives of those other people mattered ${ }^{56}$ _ but it is not about following others' experiences and ideas without due consideration. Significant for our purposes here, Simon recasts the debt the present owes to the past as a "difficult inheritance," 57 wherein "the here and now" is understood as "a moment when the past...remains before us as an endless task." 58

In our case, as philosophers of education, accepting the difficult inheritance of philosophical traditions that have been marked by exclusion is not primarily about repeating old ideas or patterns of academic performance, but about grappling with how and on what terms we are prepared to engage with the traditions we have inherited. ${ }^{59}$ Take, for example, the difficult inheritance of Richard Peters's conception of the educated man (or, as we now take him to have meant, 'the educated person'). ${ }^{60}$ On Peters's account, the hallmarks of an educated person are a highly developed capacity for autonomous reasoning and possession of the knowledge, skills, and attitudes required for full participation in the public sphere; but as critics such as Jane Roland Martin have argued, Peters's ideal is seriously lacking in that it leaves little room for the emotions, for care and responsibility for others, or for preparation for participation in the domestic sphere. ${ }^{61}$ Why then, should we continue to accept Peters's conception of the educated person as a difficult inheritance? In fact, why accept the call to remembrance at all?

According to Simon, "[a] hopeful present requires a continual reopening of the past, for only such an opening persists as a teaching." 62 To receive the past as teacher is to recognize that knowledge comes to us from outside_- "from what we are not, what we think not, and what we cannot already speak." 63 Drawing on Levinas, Simon says that we are called to greet the past with a "binding allegiance: 'Here I am.' Here I am to learn and attempt to exceed the limits of my knowledge. In my approach as apprentice, I submit myself to learn the limits of myself and, in doing so, bare myself to a wounding-a trauma inflicted by the other's [words]." 64 The ethical posture of 'Here I am' that Simon uses here refers to the unique form of passivity that underpins Levinas's conception of subjectivity as a position of inescapable indebtedness and unconditional responsibility to and for the other. ${ }^{65}$ And this existential indebtedness, Levinas says, calls us to "submit to a responsibility for that which was never my fault or deed ... [that which] has never been in my presence, has never come into memory."66

Returning to our own work, whether we like it or not, Peters's conception of the educated person continues to inform not only philosophy of education, but teacher education and curriculum design as well. The fact that education students continue to learn about the differences between education and schooling, between education and indoctrination, and between education and training, is part of the legacy that Peters and other analytic philosophers of education have left us. So while we may no longer teach our students how to do conceptual analysis per se-and, in fact, may never have undertaken such work ourselves_-current educational discourse continues to bear traces of the analytic tradition.

Acknowledging our intellectual indebtedness means that we must approach the traditions we have inherited with humility-reading, viewing and listening to the words of those who have come before us not simply in order to learn about them, but to learn from them, and to work either with or against them. It means that we must be open to questions we did not even know we had, and that we must risk learning not only what we had set out to learn, but also what might shatter our existing knowledge and certainty, in order to open up the possibility of an unforeseeable and indeterminate future. To accept our intellectual indebtedness means that we risk being changed-perhaps profoundly-by our engagement with people and ideas we might otherwise seek to avoid. Admittedly, this work will not be easy; and, as we shall see below, by insisting on a conception of subjectivity as unconditional responsibility and indebtedness to the other, Levinas set himself up for a seemingly unbearable burden in his own intellectual and personal relationship with Martin Heidegger. But, as Catherine Chalier asks, "[W] hat value does a philosophy have if it vanishes when it is put to the test?" 67 


\section{An Unbearable Burden}

In order to set the stage for this discussion, let me outline some key events in Levinas's academic life. Born into an orthodox Jewish family in Lithuania in 1906, Levinas left home at the age of 17 to study at the University of Strasbourg in France, where he was introduced to Edmund Husserl's phenomenology. In 1928, he moved to the University of Freiburg in Germany to attend Husserl's last seminar and Heidegger's first after taking up the Chair vacated by Husserl; and his doctoral thesis, The Theory of Intuition in Husserl's Phenomenology (1930), along with his other publications on Husserl and Heidegger, is credited with having introduced phenomenology to France.

In late 1932 Heidegger put his name forward to be Rector of the University of Freiburg, was elected and took office in April 1933. He joined the Nazi Party soon after and delivered his now infamous Rectorship Address on the occasion of his installation on May 27, 1933. ${ }^{68}$ In addition to revealing his allegiance to National Socialism, Heidegger focused his Address on the interplay between teacher and student - between leading and following, between the individual and the "historical and spiritual mission of the German people"-insisting that philosophy and the essence of the university be tied to the mission and will of the State. ${ }^{69} \mathrm{I}$ will not belabour here the details of Heidegger's connection to National Socialism, or the loss of most of Levinas's family members in the death camps-all of this is well documented elsewhere. Rather, my main concern is with the implications of Heidegger's political commitments for the teacher-student relationship he had with Levinas as a particularly compelling case of what it might mean to carry a burden of intellectual indebtedness one cannot reasonably (be asked to) bear.

Looking back on that time, in a 1989 symposium on Heidegger and Nazism, Levinas wrote:

I learned very early, perhaps even before 1933 and certainly after Hitler's huge success at the time of his election to the Reichstag, of Heidegger's sympathy toward National Socialism. It was the late Alexandre Koyré who mentioned it to me for the first time on his return from a trip to Germany. I could not doubt the news, but took it with stupor and disappointment, and also with the faint hope that it expressed only the temporary lapse of a great speculative mind into practical banality....

Could one question the incomparable impression produced by [Sein und Zeit], in which it immediately became apparent that Heidegger was the interlocutor and equal of the greatestthose very few-founders of European philosophy? that here was someone, this seemed obvious, all modern thought would soon have to answer? ${ }^{70}$

In light of all that had transpired, one might well say that the intellectual debt Levinas owed to Heidegger should have been cancelled. However, Levinas did not take the easy way out. Throughout his life he maintained unreserved admiration for Being and Time, saying, "I always try to relive the ambiance of those readings, when 1933 was still unthinkable;" 71 and he declared that "[anyone] who undertakes to philosophize in the twentieth century cannot not have gone through Heidegger's philosophy, even to escape it."'72

This does not mean that Levinas suffered from some form of amnesia or denial about Heidegger's actions. We can hear quite clearly the sense of betrayal and disappointment in his plea, "Doesn't [Heidegger's] silence, in time of peace, on the gas chambers and death camps lie beyond the realm of feeble excuses and reveal a soul completely cut off from any sensitivity, in which can be perceived a kind of consent to the horror?"73 And in the Nine Talmudic Readings he wrote, "One can forgive many Germans, but there are some Germans it is difficult to forgive. It is difficult to forgive Heidegger." ${ }^{4}$ Nevertheless, Levinas acknowledges that he cannot disregard the traces of Heidegger in his own work. In many of Levinas's writings there is evidence of a concerted effort to live in the tension, and to bear the burden, of intellectual indebtedness in the face of personal betrayal. Rather than denying his debt to Heidegger, Levinas took it on in his own way-wrestling with it, working with and against it. 
We will never know what shape Levinas's philosophy would have taken without the deep disappointment and betrayal he experienced in regard to Heidegger; but we do have plenty of evidence that his acknowledgement of a prior and inescapable indebtedness called forth in him the ethical demand to read and listen to Heidegger's words anew-not simply to learn about them, but to learn from them, in order to work with and against the philosophical traditions he had inherited. Where Heidegger sought to reclaim the human through Being, Levinas challenged Heidegger's reliance on ontology itself and described a subjectivity that is beyond Being. He rejected the prevailing modernist conception of no other without a self in favour of no self without another who calls it into being, "no self without another who summons it to responsibility," 75 and so on.

The example I gave earlier of Peters's conception of the educated person as a difficult inheritance in our own work obviously does not hold the same burden of personal betrayal as Levinas's indebtedness to Heidegger. However, acknowledging our intellectual indebtedness as students and scholars of philosophy of education still requires a certain humility, vulnerability and susceptibility to being touched and affected by the past, by that which we do not know and that which we might not want to know. It requires a willingness to accept the difficult inheritance bequeathed to us by committing ourselves to continually opening the past in order to make way for the possibility of a future.

\section{Response (Claudia Ruitenberg)}

The preceding three sections have given us examples of traditions that have affected our ways of thinking today, or from which we could benefit today if we paid more attention to them, but which are not without flaws. Burns has suggested that revisiting the Stoic emphasis on a detached stance toward material and other possessions would serve us well today. It is not difficult to think of instances where the focus on happiness as derived from possessions, be it of fame or fortune, could stand to be questioned. Where some turn to Buddhism for insights into such detachment, Burns reminds us of a Western tradition that similarly valued detachment. At the same time, Stoicism itself has its warts. For example, it has a strong focus on the self rather than on relationship or on the Other. As contemporary critiques of the self-centred nature of Western philosophy have become louder, how might we inherit Stoic insights critically? While the refusal to indulge emotional attachments is refreshing, we would do well to heed Burns's caution not to adopt the "seemingly callous form of individualistic rationalism" that the Stoics appeared to promote.

Another question raised by Burns's discussion is whether the Stoic idea that our beliefs about certain objects make these objects desirable and their loss a source of suffering also applies to the object of character itself. In other words, might we read the Stoics against themselves and examine their assertion of individual reason as the core of human nature and the source of flourishing? How does the way in which this belief is framed make certain things appear desirable and undesirable, or not appear at all?

Waddington's account of Thomas Jefferson's influence on Dewey is a great reminder of moral shades of grey in times that tend to black and white. Jefferson was a passionate supporter of science and a pioneer in the development of public education; he was also a supporter of slavery and personally owned and traded slaves. Waddington writes that "it is possible to recover traditions from Jefferson (and from Dewey and other thinkers) and simultaneously acknowledge that there is a significant amount of baggage that accompanies these traditions. Perhaps, as philosophers and historians of education, this "eyes-wide-open" reconstruction is one of our pressing tasks." Waddington's term "recover" is particularly apt. Recovery means not going in search of a tradition that had no bearing on our lives before but rather retrieving a tradition that, like a shipwreck hiding on the ocean floor, has been affecting the currents of our lives all along. We should not adopt the ideas of Jefferson or Dewey wholesale but can still benefit from understanding Dewey's concern, 70 years ago, about a lack of true 
commitment to democratic institutions, about a shallow engagement with the formal institutions of democracy rather than with democratic culture.

Chinnery gives us two examples of difficult, although not equally difficult, inheritance. She writes that even when the atrocities of the Second World War, which affected Levinas personally, would have made it reasonable for Levinas to definitively turn his back on Heidegger's work or disavow any intellectual debt to it, "Levinas did not take the easy way out" and did not choose to forget or deny Heidegger's actions. Without wanting to draw any parallels between the political sympathies of Heidegger and Peters, for such a suggestion would be entirely misplaced, we can ask whether, if Levinas could muster the intellectual courage and honesty to take on Heidegger's tradition "eyes-wideopen," it would not behoove us to take on the inheritance of the ideas of Richard Peters and other Anglo-analytic philosophers of a certain generation? bell hooks explains very clearly how she can continue to learn from and be inspired by the work of Paulo Freire without turning a blind eye to the sexism in his work:

There has never been a moment when reading Freire when I have not remained aware of not
only the sexism of the language but the way he (like other Third World progressive political
leaders, intellectuals, critical thinkers such as Fanon, Memmi, etc.) constructs a phallocentric
paradigm of liberation-wherein freedom and the experience of patriarchal manhood are
always linked as if they are one and the same. For me this is always a source of anguish for it
represents a blind spot in the vision of men who have profound insight. And yet I never wish
to see a critique of this blind spot overshadow anyone's (and feminists in particular) capacity to
learn from the insights. ${ }^{76}$

She summarizes her point with a succinct phrase I have repeated often: "critical interrogation is not the same as dismissal." "77 Likewise, critical interrogation of Peters's work is not the same as dismissal, and if we feel anguish in studying and learning from Peters's work because we feel it is somehow a betrayal of our feminist convictions, then hopefully intellectual and moral virtues such as courage, honesty, and the acknowledgement of intellectual indebtedness can keep us turning to the work rather than away from it.

I began with a reference to the question posed to Jacques Derrida, "If you had a choice, what philosopher would you have liked to have been your mother?" I recounted that Derrida answered that his mother could not have been a philosopher, and that a philosopher could not have been his mother, because the figure of the philosopher has been a masculine figure, the figure of the father. That is one "warty" part of the tradition of Western philosophy that Derrida has inherited, but it has not been reason for him to turn away from or deny that tradition, but rather to commit to a critical engagement with it. Through such a critical engagement the inheritance can be redirected. This allows Derrida to continue his answer by saying, "My mother as philosopher would be my granddaughter, for example. An inheritor. A woman philosopher who would reaffirm the deconstruction. And consequently, would be a woman who thinks. Not a philosopher. I always distinguish thinking from philosophy. A thinking mother-it's what I both love and try to give birth to."

Leaving aside the question of whether the concept and term "philosophy" must be surrendered to masculinist history and replaced by the concept and term "thinking," Derrida's answer underscores that the point of engaging with traditions is not to get stuck in them, but rather to change the future. His mother couldn't have been a philosopher, but his granddaughter can be. My grandmother could not have been an "educated man", but I can (hypothetically speaking) be an "educated person." So let me close by endorsing Derrida's words in Archive Fever.

The question of the archive is not... a question of the past. It is not the question of a concept dealing with the past which already might be at our disposal or not at our disposal, ... [but rather] a question of the future, the question of the future itself, the question of a response, of a promise and of a responsibility for tomorrow. ${ }^{78}$ 


\section{Acknowledgments}

An earlier version of this symposium was presented at the 2009 meeting of the Canadian Philosophy of Education Society.

\section{About the Authors}

David P. Burns is a Ph.D. student in the Department of Educational Policy Studies at the University of Alberta. His current research interests include virtue education, character education, moral education, and professional ethics in education. He can be reached at dburns@ualberta.ca. Ann Chinnery is an Assistant Professor in the Faculty of Education at Simon Fraser University. Her research interests include continental ethics; moral education; and the complexities of preparing teachers for work in increasingly diverse classrooms. She can be reached at achinner@sfu.ca. Claudia Ruitenberg is an Assistant Professor in the Department of Educational Studies at the University of British Columbia. Her research interests include discursive performativity and its relation to hate speech and censorship in education; agonistic political theory and the implications for political education; philosophical research methods; and queer theory. She can be reached at claudia.ruitenberg@,ubc.ca. David I. Waddington is an Assistant Professor of Educational Studies at Concordia University. His current research interests include Dewey's early work, the history of progressive education, and new approaches to science and technology education. He can be reached at dwadding@education.concordia.ca

${ }^{1}$ The authors contributed equally to the symposium and are listed in alphabetical order.

${ }^{2}$ Kirby Dick and Amy Kofman (Directors), Derrida [Motion picture] (New York: Zeitgeist Films, 2002).

${ }^{3}$ Ibid.

${ }^{4}$ Claudia Ruitenberg, "Education as Séance: Specters, Spirits, and the Expansion of Memory," Interchange 40, no. 3 (2009): 295-308.

${ }_{5}$ Michael Naas, Taking on the Tradition: Jacques Derrida and the Legacies of Deconstruction (Stanford, CA: Stanford University Press, 2003).

${ }^{6}$ Ibid., xvii, emphasis added.

7 Roger I. Simon, Sharon Rosenberg, and Claudia Eppert, eds., Between Hope \& Despair: Pedagogy and the Remembrance of Historical Trauma. (New York: Rowman and Littlefield, 2000), 6.

${ }^{8}$ Cf. William Perry, Jr., Forms of Intellectual and Ethical Development in the College Years: A Scheme (New York: Holt, Rinehart, and Winston, 1970).

${ }^{9}$ Seneca, To Helvia on Consolation, trans. John W. Basore (London: William Heinemann, 1932a), X.8-11.

${ }^{10}$ Ibid., X.10.

${ }^{11}$ Julia Annas, "Seneca: Stoic Philosophy as a Guide to Living," in ed. J. Welchman, The Practice of Virtue: Classic and Contemporary Readings in Virtue Ethics (Indianapolis, IN: Hackett Publishing Company, 2006), 158.

12 Seneca, On the Happy Life, trans. John W. Basore (London: William Heinemann, 1932b), III.2-4.

${ }^{13}$ Seneca, Epistles LXXVI, trans. E. Phillips Barker (Oxford: Clarendon Press, 1932c), LXXVI.10-11.

${ }^{14}$ Seneca, On the Happy Life, XV.3.

15 Tad Brennan, The Stoic Life: Emotions, Duty and Fate (Oxford: Clarendon Press, 2005).

16 Seneca, On the Happy Life, XXII.2-3.

17 Ibid., XXII.1-2.

18 Aristotle, The Nicomachean Ethics, trans. James A. K. Thomson (London: Penguin, 1953), 1099b.

${ }^{19}$ Ibid.

20 Zosia Bielski and Jane Armstrong, "iPod Loyalists: They'd Rather Fight than Ditch," The Globe and Mail, November 15, 2008, http://www.theglobeandmail.com/news/national/article722823.ece (accessed April 29, 2009).

21 Mark Holowchak, "Education as Training for Life: Stoic Teachers as Physicians of the Soul," Educational Philosophy and Theory 41, no. 2 (2009): 166-184. 
22 Ibid., 175.

${ }^{23}$ For an example see Claudia Card, "Stoicism, Evil, and the Possibility of Morality," Metaphilosophy 29, no. 4 (1998): 245-253.

${ }^{24}$ For an example see Martha C. Nussbaum, The Therapy of Desire: Theory and Practice in Hellenistic Ethics (Princeton, NJ: Princeton University Press, 1994).

${ }^{25}$ Seneca, To Helvia on Consolation.

${ }^{26}$ John Dewey to Max C. Otto, Dewey Correspondence, 1939.10.23.

${ }^{27}$ John Dewey, Freedom and Culture (New York: G.P. Putnam, 1939), 6.

28 Ibid., 13.

${ }^{29}$ Thomas Jefferson, Notes on Virginia (Richmond: J.W. Randolph, 1853), 177.

30 John Dewey to Max C. Otto, Dewey Correspondence, 1939.11.28.

31 Ibid. One could probably make an argument that this idea is implicit in Dewey's thought before Jefferson, but the fact remains that Dewey explicitly says that it "came to him" from Jefferson.

32 Ibid., 158.

33 Ibid., 158.

34 Ibid., 159.

35 John Dewey, The Early Works, vol. 4, ed. Jo Ann Boydston (Carbondale: Southern Illinois University Press, 1973).

36 Ibid., 15.

${ }^{37}$ John Dewey, "Presenting Thomas Jefferson," in The Living Thoughts of Thomas Jefferson (New York: Longmans, 1940), 2.

38 Notably, Jefferson received significant criticism from his political opponents for his interest in science. My favorite criticism in this regard is a anti-Jefferson poem which reads, in part, as follows: "Go, wretch, resign the presidential chair/Disclose thy secret measures foul or fair/Go, search, with curious eye, for horned frogs/Amongst the wild wastes of Louisiana bogs/Or where Ohio rolls his turbid stream/Dig for huge bones, thy glory and thy theme." See Silvio E. Bedini, Thomas Jefferson: Statesman of Science (New York: MacMillan, 1990), 392.

${ }^{39}$ Bedini, Thomas Jefferson: Statesman of Science, 95-96.

${ }^{40}$ Ibid., 493.

${ }^{41}$ Dewey, Freedom and Culture, 158.

42 Dewey, The Living Thoughts of Thomas Jefferson, 12.

${ }^{43}$ Carl F. Kaestle, Pillars of the Republic (New York: Hill and Wang, 1983), 8-9; Bedini, Thomas Jefferson: Statesman of Science, 449-460. Note that this should certainly not be read as an endorsement of Jefferson's scheme, which had some elitist elements.

44 Thomas Jefferson, Notes on Virginia, 173-174.

${ }^{45}$ Lucia Stanton, "Those Who Labor for My Happiness: Thomas Jefferson and His Slaves," in Jeffersonian Legacies, ed. Peter S. Onuf (Charlottesville: University Press of Virginia, 1993), 148.

${ }^{46}$ Eugene A. Foster et al., "Jefferson Fathered Slave's Last Child," Nature 396 (November 1998): 27-28; Thomas Jefferson, Notes on Virginia, $142 \mathrm{ff}$.

${ }^{47}$ John Dewey, Reconstruction in Philosophy (New York: Beacon Press, 1948), xxvii.

48 Given this fact, it is ironic that Palladium Press, "an official affiliate of the National Rifle Association," republished Dewey's The Living Thoughts as part of a series they refer to as the "Firearms Classics Library." See "The Living Thoughts of Thomas Jefferson," The Open Library, http://openlibrary.org/b/OL16244499M/ living-thoughts-of-Thomas-Jefferson (accessed June 29, 2009).

${ }^{49}$ Dewey, Freedom and Culture, 157.

${ }^{50}$ Eamonn Callan has contributed some insight on this question in "Beyond Sentimental Civic Education," American Journal of Education 102, no. 2 (1994): 190-221.

${ }^{51}$ Emmanuel Levinas, "Reflections on the Philosophy of Hitlerism," trans. Seán Hand, reprinted in Critical Inquiry 17, no. 1 (1990): 63-71.

${ }^{52}$ Simon et al., Between Hope \& Despair, Roger I. Simon, The Touch of the Past: Remembrance, Learning, and Ethics (New York: Palgrave Macmillan, 2005).

${ }^{53}$ Emmanuel Levinas, Otherwise than Being or Beyond Essence, trans. Alphonso Lingis (The Hague: Martinus Nijhoff, 1981); Emmanuel Levinas, "Diachrony and Representation," in Time and the Other (and other additional essays) trans. Richard Cohen (Pittsburgh: Duquesne University Press, 1987). 
54 Jacques Derrida, Specters of Marx: The State of the Debt, the Work of Mourning, and the New International, trans. P. Kamuf (New York: Routledge, 1994); Jacques Derrida, Archive Fever: A Freudian Impression (Chicago: University of Chicago Press, 1996); Jacques Derrida, Of Hospitality: Anne Dufourmantelle Invites Jacques Derrida to Respond, trans. R. Bowlsby (Stanford, CA: Stanford University Press, 2000).

55 Simon, Touch of the Past, 133.

${ }^{56}$ Ibid.

${ }^{57}$ Ibid., 112.

58 Geoffrey Bennington, Interrupting Derrida (New York: Routledge, 2000), 140.

${ }^{59}$ Simon, Touch of the Past, 134.

${ }^{60}$ Richard S. Peters, Ethics and Education (London: George Allen \& Unwin, 1966); Richard S. Peters, "Education and the Educated Man," in A Critique of Current Educational Aims, eds. Robert F. Dearden, Paul H. Hirst, and Richard S. Peters (London: Routledge \& Kegan Paul, 1972).

${ }^{61}$ Jane Roland Martin, “The Ideal of the Educated Person," Educational Theory 31, no. 2 (1981): 97-109.

62 Simon, Touch of the Past, 112.

${ }^{63}$ Ibid.

${ }^{64}$ Ibid., 54, emphasis in original.

${ }^{65}$ Levinas, Otherwise than Being.

${ }^{66}$ Levinas, "Diachrony and Representation," 111.

${ }^{67}$ Catherine Chalier, What Ought I to Do? Morality in Kant and Levinas, trans. Jane Marie Todd (Ithaca, NY: Cornell University Press), 13.

${ }^{68}$ Martin Heidegger, "The Self-Assertion of the German University," in Martin Heidegger and National Socialism, eds. Gunther Neske and Emil Kettering (New York: Paragon House, 1990).

${ }^{69}$ Arnold I. Davidson, "Questions Concerning Heidegger: Opening the Debate," Critical Inquiry 15, no. 2 (1989): $411,418$.

${ }^{70}$ Emmanuel Levinas, “As if Consenting to Horror,” Critical Inquiry 15, no. 2 (1989): 485.

71 Emmanuel Levinas, Ethics and Infinity: Conversations with Philippe Nemo, trans. Richard A. Cohen (Pittsburgh: Duquesne University Press, 1985), 38.

72 Ibid., 42.

${ }^{73}$ Levinas, “As if Consenting," 487.

${ }^{74}$ Emmanuel Levinas, Nine Talmudic Readings, trans. Annette Aronowicz (Bloomington, IN: Indiana University Press, 1994), 25.

75 Paul Ricoeur in Peter Kemp, "Ricoeur between Heidegger and Levinas: Original Affirmation between Ontological Attestation and Ethical Injunction," in Paul Ricoeur: The Hermeneutics of Action, ed. Richard Kearney, (London: SAGE, 1996), 46.

${ }^{76}$ bell hooks, Teaching to Transgress: Education as the Practice of Freedom (New York: Routledge, 2004), 49.

77 Ibid.

${ }^{78}$ Derrida, Archive Fever, 36. 